\title{
Bijsluiter bij: Buy-to-let gewikt en gewogen*
}

\author{
Marcel Visser ${ }^{* *}$
}

\section{Inleiding}

Het is druk op de Nederlandse huizenmarkt. Het afgelopen jaar 2017 vond er met ruim 240.000 verkochte woningen een recordaantal transacties plaats (ruimschoots meer dan het oude record uit 2006). Bezichtigingen van een uurtje met meer dan vijftig geïnteresseerden tegelijkertijd zijn aan de orde van de dag, net als overbieden en overboden worden.

De koopdrukte is een landelijk fenomeen: in élke provincie en voor élk type woning werd afgelopen jaar een alltime record in transactieaantallen genoteerd (Kadaster, 2017). Prijzen zijn navenant gestegen. Landelijk liggen de prijzen gemiddeld inmiddels 20 procent boven het dal van 2013 (bijna op piekniveau van 2008; prijsindex Kadaster). In de Randstad zijn de prijzen zelfs extreem gestegen (zo'n 30-40 procent boven het dal). Koploper Amsterdam is aangekomen op een nooit eerder gezien prijsniveau, circa 60 procent hoger dan vijf jaar geleden.

Tegelijkertijd zijn de huurprijzen hard gestegen, zowel in de sociale sector als in de vrije sector. Bij gebrek aan alternatieven besteden huurders in de particuliere vrije sector inmiddels gemiddeld meer dan 40 procent van hun inkomen aan woonlasten, en geregeld zelfs tot 50 procent (Lokale Monitor Wonen, 2018). Er staat spanning op zowel de koop- als de huurmarkt. Er is een acuut tekort aan (passend) aanbod. Hele groepen dreigen verstoken te blijven van betaalbaar wonen (of van zelfstandig wonen) en er wordt inmiddels gesproken van een nieuwe woningnood.

Tegen deze achtergrond van spanning op de woningmarkt gaat het rapport Buy-to-let gewikt en gewogen (Aalbers e.a., 2018) in op de recente opkomst van buy-to-let op de Nederlandse woningmarkt. Er is een nieuwe groep spelers actief (particulieren) die woningen opkoopt voor de verhuur. Welke invloeden heeft buy-to-let op de woningmarkt? Draagt buy-to-let bij aan een gezonde woningmarkt? Is bijsturing van deze snel gegroeide praktijk nodig? RaboResearch denkt van wel en stelde recent voor om opportunistische beleggers af te schrikken (Lennartz, Baarsma \& Vrieselaar, 2018).

Het rapport Buy-to-let gewikt en gewogen stelt: 'deze nieuwe spelers op de koopmarkt verdringen potentiële eigenaars-bewoners' en 'buy-to-let drijft de koopprijzen verder op'. Het inventariseert tevens tientallen mogelijke beleidsmaatregelen (hoofdstuk 3) en komt ook zelf met een aantal beleidsaanbevelingen.

Het rapport adresseert een actueel punt. De opkomst van buy-to-let in Nederland werd reeds in 2016 als risicovol bestempeld (Martens, 2016), en deze geluiden zijn ook in de media te horen.

* $\quad$ Artikel ingediend 6 juni 2018.

** Dr. Marcel Visser is financieel econometrist. www.linkedin.com/in/marcel-visser 
De uitnodiging van de redactie om een commentaar bij dit onderwerp te geven heb ik opgevat als opdracht om kritisch maar constructief bij te dragen.

Om kritisch te beginnen: Het rapport heeft zo nu en dan de schijn tegen. Zo meldt de samenvatting 'wordt inmiddels (...) dertig procent van de woningen van minder dan 50 vierkante meter opgekocht door verhuurders', zónder daarbij te vermelden dat dit al jaren een populaire categorie is bij beleggers en dat dit percentage in 2016 niet hoger ligt dan in 2006... (op basis van de eigen tabel (tabel 2.2) in het rapport), niets nieuws dus. Daarnaast tast het rapport in het duister over de invloed van particuliere beleggers op de prijsvorming: 'het exacte effect van particuliere investeerders en particuliere beleggers op de prijsontwikkeling is vooralsnog onduidelijk' (p. 23), om zich vervolgens te bedienen van het argument 'dat elke koper meer, een effect heeft op de prijs' (p. 23) en in de eindconclusie wel erg stellig te melden: 'buy-to-let drijft de koopprijzen echter verder op'. Waar het rapport oordeelt dat buy-to-let zorgt voor verdringing van aspiranteigenaars (onder meer op basis van Kadasterdata), verwijst het niet naar een analyse van het Kadaster die concludeert dat verdringing vooralsnog alleen zichtbaar lijkt in Amsterdam (De Vries, Brugmans \& Harleman, 2017). En nog een voorbeeld: het rapport werpt de vraag op 'of het mogelijk is de positieve effecten van investeerders te stimuleren en tegelijkertijd de negatieve kanten af te remmen of geheel te voorkomen' (p. 8). Een analyse van de positieve effecten ontbreekt en van de twaalf uiteindelijke beleidsaanbevelingen blijken er twaalf remmend te werken en is er hooguit één maatregel die positieve effecten van investeerders direct stimuleert (korting op grondprijs in ruil voor restricties bij ontwikkeling huurbouw). ${ }^{1}$

Er is dus een zekere schijn van eenzijdigheid en die wordt niet weggenomen door in de titel 'wikken en wegen' op te nemen. En dat is zonde! Er is namelijk een buyto-let-boom. Hieraan zijn risico's verbonden. En er is relatief weinig kennis en data voorhanden over de Nederlandse buy-to-let-ontwikkeling. Het uitgebreide rapport is dan ook zeer welkom en aanbevelenswaardig voor beleidsmakers en andere geïnteresseerden, en voorziet in historische en internationale achtergronden en tientallen beleidsmogelijkheden. Lees wel eerst deze bijsluiter, want die bevat belangrijke informatie om tot een evenwichtig beeld te komen.

\section{Toegankelijkheid en betaalbaarheid van wonen centraal}

Terecht stelt Buy-to-let gewikt en gewogen de toegankelijkheid en betaalbaarheid van wonen centraal. Passend wonen is een grondrecht om goede redenen. Lange wachttijden, woekerhuren en hoge koopprijzen horen daar niet bij. Woningmarktbeleid behoort te sturen op toegankelijkheid en betaalbaarheid, alsmede op kwaliteit en leefbaarheid van wonen. Private partijen streven een hoog rendement na, zij kunnen vanuit beleidsoogpunt dienen als een middel om deze beleidsdoelen te bereiken, maar het is bekend dat het uitgangspunt van rendement voor private partijen al snel op gespannen voet kan komen te staan met het grondrecht van wonen. 


\section{Achtergronden}

Eerst nog een keer: wat is buy-to-let? Het begrip buy-to-let gaat over specifieke transacties op de koopwoningmarkt, namelijk de aankoop van reguliere bestaande koopwoningen (geen vakantiebungalows) om deze vervolgens te verhuren. Dit in tegenstelling tot bijvoorbeeld de aankoop voor eigen bewoning, en ook in tegenstelling tot de ontwikkeling en bouw van nieuwe woningen voor de verhuur. Een buy-to-let-transactie onttrekt een koopwoning (eigenaar-bewoner) en voegt doorgaans een huurwoning toe: een omzetting binnen de woningvoorraad. Indien een woning voor andere doeleinden, zoals toeristische verhuur (denk aan Airbnb), wordt ingezet, dan krimpt daarmee de beschikbare woningvoorraad.

In de praktijk worden buy-to-let-transacties meestal gedaan door kleine beleggers (particulieren) met een beperkt aantal woningen in bezit. Grote partijen opereren doorgaans complexmatig. Financiering gebeurt vaak volledig of grotendeels op basis van eigen geld. Koop-voor-verhuur is van alle tijden, was decennialang een nichemarkt, maar sinds ongeveer 2014 is er een opvallende stijging (landelijke verdrievoudiging) in het aantal buy-to-let-transacties; in Amsterdam en Rotterdam is het punt ontstaan dat 25 procent van de woningtransacties uit buy-to-let bestaat (De Nederlandsche Bank (DNB), Overzicht Financiële Stabiliteit voorjaar 2018). Deze transacties vinden vooral plaats aan de onderkant van de markt: buyto-let concentreert zich bij de kleinere objecten (tot $100 \mathrm{~m} 2$, vooral tot $50 \mathrm{~m} 2$ ) en de goedkopere objecten (tot $€ 150.000$ à $€$ 200.000); in Amsterdam loopt dit verder door. Ofwel het segment dat voorheen werd gekarakteriseerd als starterswoningen. Daar zit ten opzichte van de koopprijs het hoogste huurrendement.

De recente buy-to-let-trend valt samen met de eveneens recente herleving van de particuliere huursector na een generatieslange periode van krimp. Na de Tweede Wereldoorlog bestond de Nederlandse woningvoorraad voor ongeveer 60 procent uit particuliere huurwoningen; destijds veel groter dan de koopvoorraad (minder dan 30 procent) en de corporatievoorraad (minder dan 15 procent). Rond de financiële crisis van 2008 was daar nog zo'n 11,5 procent particuliere verhuur van over. Deze krimp over een periode van 65 jaar is in grofweg twee fases in te delen: eerst in hoofdzaak in het kielzog van een veertig jaar lange opkomst van de corporatievoorraad (van 15 naar 40 procent in 1985, terwijl het aandeel particuliere huur daalde naar circa 20 procent), en vervolgens vooral door een 25 jaar lange opkomst van de koopvoorraad (van 40 naar circa 55 procent). Over recente jaren is een trendbreuk zichtbaar en stijgt het aandeel particuliere verhuur van 11,5 procent in 2012 naar zo'n 13,3 procent in 2017 (percentages op basis van het Centraal Bureau voor de Statistiek (CBS) en Buy-to-let gewikt en gewogen). Deze groei van particuliere verhuur ging vooral ten koste van de corporatievoorraad (zoals de Vestia-verkopen) en in mindere mate van de koopvoorraad (buy-tolet-transacties). Het aantal woningen in handen van kleine verhuurders telde anno 2016 ongeveer 323.000 of 4,4 procent van de voorraad (De Vries e.a., 2017). Over 2016 en 2017 kwamen daar respectievelijk ongeveer 19.000 en 25.000 gevallen bij (data DNB). Het huidige buy-to-let-tempo ligt daarmee op circa 0,3 procent van de woningvoorraad per jaar. De opkomst van buy-to-let staat in Nederland in de kinderschoenen in vergelijking met enkele andere lan- 
den. In het Verenigd Koninkrijk vond een sterke opkomst plaats vanaf halverwege de jaren negentig en er zijn schattingen dat grofweg één op de zes huizen in het Verenigd Koninkrijk van kleine particuliere beleggers is.

De herleving van particuliere verhuur valt goed te begrijpen. $\mathrm{Na}$ de financiële crisis van 2008 is een klimaat van aanhoudend lage rentes ontstaan. Wie zijn spaargeld niet belegt, teert in. De rente op Nederlandse tienjarige staatobligaties zakte in 2014 door het fiscale break-evenpoint van 1,2 procent, en in 2015 deden de spaarrentes dat ook. Inmiddels staan deze in de buurt van de 0,0 procent. Dit heeft een stroom van particulieren in gang gezet die méér dan 0,0 procent rendement willen halen. Een belegging die periodieke huurpenningen oplevert is dan een interessant alternatief, bijna zoiets als maandelijkse rente op de spaarrekening. De drijvende krachten achter de buy-to-let-boom zijn de lage rente en de hoge huren.

\section{Buy-to-let-verdienmodel in de praktijk}

Neem een appartement van $50 \mathrm{~m} 2$ in de Amsterdamse Pijp, vraagprijs $€ 350.000$ (mei 2018). Voor een belegger vertegenwoordigt dit appartement in de huidige markt huurinkomsten in de orde van grootte van $€ 1600$ per maand. Deze huurstroom genereert een bruto jaarrendement op aankoopkosten van ongeveer 5,3 procent, waar na aftrek van exploitatiekosten ${ }^{2}$ ongeveer 4,0 procent netto rendement van over blijft (vóór fiscale heffing in box 3). Dat is minder dan een aantal jaren geleden op een spaarrekening, maar bij gebrek aan alternatieven nu tóch interessant. En, hoe lager de rendementseis van de belegger, hoe hoger zijn transactieprijs mag zijn. Mocht deze belegger tevreden zijn met een netto huurrendement van 3,0 procent (in plaats van de hiervoor genoemde 4,0 procent), dan vertegenwoordigt dit appartement voor hem een potentiële huur-/beleggingswaarde van $€ 460.000 .^{3}$ Bij een eis van netto 2,0 procent ligt dit op bijna $€ 700.000$. Dit voorbeeld toont:

- 'Woekerhuren' geven nog géén woekerrendementen voor beleggers.

- Bij een spaarrente van 0 procent is de sky the limit voor buy-to-let-koopprijzen; beleggers hebben 'soft budget constraints'.

- Hoge huren geven aanleiding tot hoge buy-to-let-koopprijzen.

- Een hoge overdrachtsbelasting voor buy-to-let-transacties verandert de uitkomst van de rekensom niet wezenlijk. ${ }^{4}$ Dit geldt in de praktijk waarschijnlijk ook voor andere fiscale maatregelen.

- Maatregelen tegen hoge huren hebben wél een groot effect op de uitkomst van de rekensom en dus op de beleggingswaarde van woningen. ${ }^{5}$

\section{Hoge huren}

Buy-to-let floreert bij hoge huren. Die hoge huren komen niet uit de lucht vallen, maar zijn het gevolg van verschillende woningmarktontwikkelingen over het afgelopen decennium. Ten eerste is de vraag naar huurwoningen sterk gegroeid. Ten tweede is de juridische mogelijkheid om hoge huren te rekenen sterk ver- 
ruimd. Aanzienlijke groepen zitten klem. De grote vraag naar woningen zet mensen aan om hun financiële grenzen op te zoeken en leidt tot de bereidheid om hoge huren te dragen.

Enkele omstandigheden die ten grondslag liggen aan de sterke vraaggroei naar huurwoonruimte zijn:

- Het algemene woningtekort is de afgelopen jaren, en vooral sinds 2012, scherp toegenomen. Voor 2018 wordt het tekort becijferd op zo'n 200.000 woningen (Faessen e.a., 2017). Ook transformaties (van bedrijfshuisvesting naar woningen) hebben de groei van het tekort niet voorkomen. In 2008 werd het woningtekort nog geschat op 129.000 woningen. Destijds werden er ruim 80.000 woningen per jaar gebouwd. Na correctie voor woningonttrekkingen was dit net voldoende om de groei in het aantal huishoudens op te vangen, waardoor het woningtekort met enkele duizenden per jaar afnam. In de jaren na aanvang van de crisis was er een grote terugval in nieuwbouw tot minder dan 60.000 woningen per jaar (zelfs minder dan 50.000 woningen jaarlijks van 2012-2015). Inbegrepen is de terugval van de bouwproductie van corporatiewoningen van 25.000 in 2009 tot 7000 in 2014. Deze terugval is symptomatisch voor het anticyclisch bouwen van de corporatiesector sinds de verzelfstandiging van de woningcorporaties in $1995^{6}$ (Tweede Kamer, 2013), en tevens wordt de bouwproductie van woningcorporaties belemmerd door de verhuurdersheffing die sinds 2013 geldt voor sociale verhuurders.

- Het lokale woningtekort kan extra nijpend zijn door lokale factoren, zoals de gegroeide trek naar de stad, de intocht van expats ${ }^{7}$ en de opkomst van toeristische verhuur (Airbnb; zie hieronder).

- Een grote groep klanten van de sociale-huursector is niet meer welkom bij de corporaties. Middeninkomens komen noodgedwongen terecht in de vrije-sectorhuurmarkt. Sinds 2011 geldt er een inkomensgrens van $€ 36.798$ per huishouden (niveau 2018) voor toewijzing van woningen in de sociale-huursector (uitzonderingen daargelaten). Dat is het modale inkomen van een eenverdiener. Meerpersoonshuishoudens met een modaal huishoudinkomen zijn sindsdien uitgesloten van de sociale sector. Dit zorgt voor extra vragers op de koopmarkt en op de vrije-sectorhuurmarkt. Tegelijkertijd verhindert de nieuwe Woningwet (2015) corporaties te bouwen voor de middeninkomens. ${ }^{8}$

- Jonge starters kunnen minder snel dan voorheen de koopwoningmarkt op. Door aangescherpte leennormen, de vereiste van eigen geld en de toename van flexcontracten komt een kleiner deel van deze groep in aanmerking voor een hypotheek. De fiscale verplichting tot aflossen zet starters op een flinke achterstand ten opzichte van doorstromers (die hun oude aflossingsvrije ${ }^{9}$ rechten mogen meenemen). Meer jonge starters zoeken daarom hun heil op de huurmarkt.

- In toeristische steden (zoals Amsterdam) is er sprake van onttrekking aan de beschikbare woningvoorraad ten behoeve van toeristische verhuur. Het aantal Airbnb-adressen in Amsterdam is sinds 2011 gegroeid van bijna nihil naar meer dan 30.000 (die geheel of gedeeltelijk onttrokken worden). Dat is méér dan de Amsterdamse nieuwbouwproductie over de jaren 2011-2016. ${ }^{10}$ En dat 
is méér dan het dubbele van het aantal buy-to-let-transacties over dezelfde periode. ${ }^{11}$

Daarnaast zijn de afgelopen jaren de mogelijkheden verruimd om hoge huren te vragen:

- In de sociale-huursector (onder de liberalisatiegrens van $€ 710$ ) is de inkomensafhankelijke huurverhoging ingevoerd (2013). Corporaties staan onder druk om huurverhogingen door te voeren vanwege de jaarlijkse verhuurdersheffing (sinds 2013).

- Door een wijziging in het huurpuntensysteem in 2015 (met name dat de WOZ-waarde sindsdien meetelt) scoren veel voormalig gereguleerde woningen (tot $€ 710$ ) nu een puntenhuur boven de liberalisatiegrens. In zulke gevallen zijn verhuurders niet gebonden aan een maximale huurprijs. ${ }^{12}$ In het praktijkvoorbeeld hierboven van het appartement in de Amsterdamse Pijp betekent dit een huursprong van minder dan $€ 700$ per maand naar $€ 1600$ per maand. Veel woningen zijn hierdoor een interessante belegging geworden.

\section{Verdringing van starters of transitie van woningmarkt?}

Voor verkopers is elke geïnteresseerde koper meegenomen, en al helemaal wanneer ten tijde van stagnerende verkopen een buy-to-let-koper dan nog net degene is die een verkoper uit de brand helpt. Voor starters speelt mogelijk nog iets anders. Zoals hierboven beschreven, kunnen starters minder snel dan voorheen de koopmarkt op. Mogelijk willen starters ook minder snel. Het is goed denkbaar dat een toenemend aantal starters liever zou willen huren dan kopen (maar dan wel tegen betaalbare prijzen). Deze trend in de woonwens naar huren was zichtbaar onder starters de eerste jaren na de crisis van 2008 (Ministerie van Binnenlandse Zaken en Koninkrijksrelaties, 2015). Meer starters zouden dan aanvankelijk een starterswoning huren en wanneer ze toe zijn aan kopen, zouden ze zich richten op eengezinswoningen. De start van de wooncarrière is doorgaans omgeven met onzekerheid en dynamiek: wisseling van baan, van woonplaats, de vorming van een gezin, en veranderende woonwensen. Daar past de flexibiliteit van een huurwoning bij. Gezien de hoge transactiekosten die gepaard gaan met de aanschaf van een koopwoning, zou zo'n aanschaf logischerwijs ook beter bij een lange woontermijn passen. Het zou goed kunnen dat we ons middenin een markttransitie bevinden, waarbij doorstromen binnen de koopmarkt en de koopladder niet meer de norm zijn, maar koopstarters gericht zijn op een woning voor de lange termijn en dat de structuur van onze woningmarkt meer gaat lijken op die van de landen om ons heen (Martens, 2009, 2016). ${ }^{13}$

Zo bezien vervult buy-to-let mogelijk een nuttige rol in het voorzien van een nieuwe vraag naar huurwoningen. In dat geval is het de vraag of er wel van verdringing kan worden gesproken. Buy-to-let zorgt in ieder geval niet voor onnodige onttrekkingen aan de woningvoorraad, zoals toeristische verhuur en buy-toleave (kopen als belegging zonder dat er iemand gaat wonen) dat wel doen. ${ }^{14} \mathrm{Bij}$ 
buy-to-let is sprake van een omzetting binnen de woningvoorraad (koop wordt huur) en dan dient de vraag te zijn of de voorraad hiermee per saldo beter aansluit op de huidige en toekomstige woonvraag in de markt, en of deze ontwikkeling bijdraagt aan de betaalbaarheid en toegankelijkheid van wonen.

In die optiek dienen nieuwkomers op de huizenmarkt tijdens zo'n huurstart wel vermogen te kunnen opbouwen, anders komen ze vast te zitten. Vermogen opbouwen werkt alleen met betaalbare huren. En daar wringt nogal eens de schoen. Om te kunnen sparen moet een huur makkelijk betaalbaar zijn. Volgens de huurtool van het Nederlands Instituut voor Budgetvoorlichting (Nibud) betekent dit dat een huishouden met een verzamelinkomen van $€ 40.000$ een huur aankan tot circa $€ 900$ per maand. ${ }^{15}$ Om ruimschoots te kunnen sparen is een lagere huur nodig. Bijna een derde van de middeninkomens kan geen huur boven de $€ 700$ per maand betalen (Planbureau voor de Leefomgeving, 2017).

\section{Buy-to-let als luxe dienst voor expats en hoger opgeleiden (en voor studenten)}

Een ander narratief is dat buy-to-let leidt tot huurwoningen voor expats en hoger opgeleiden enerzijds, en tot studentenkamers anderzijds. Voor expats en hoger opgeleiden wordt dat soort woningen vaak hoogwaardig afgewerkt en gemeubileerd aangeboden. Een dienst binnen het luxe segment. Een blik op Funda of Pararius bij de gemeubileerde woningen en Engelstalige advertenties versterkt dit vermoeden. Een luxe dienst wordt afgenomen op basis van vrijwilligheid, niet uit nood, en leent zich dus veel meer voor de vrije markt dan reguliere verhuur. Verkamering (voor studenten) is sterk gereguleerd en gebonden aan maximale huurprijzen. ${ }^{16}$ In beide gevallen versterkt buy-to-let mogelijk segregatie, ${ }^{17}$ maar leidt het niet direct tot huurders met betaalbaarheidsproblematiek. Helaas zijn er geen betrouwbare data of studies voorhanden om hier binnen de Nederlandse context nu meer over te zeggen. Wat we wél kunnen zeggen is dat gezien de opkomst en de aantallen van buy-to-let buiten de vier grote steden (zie hieronder), de doelgroep waarschijnlijk veel breder is dan expats, hoger opgeleiden en studenten.

\section{Nieuwe risico's door buy-to-let}

In haar Overzicht Financiële Stabiliteit Voorjaar 2018 besteedt De Nederlandsche Bank aandacht aan buy-to-let. De toestroom van een nieuwe groep kopers kan de prijzen doen stijgen en kan reguliere kopers tot risicovol gedrag aanzetten. Buyto-let kan, via hoge prijzen, ook segregatie in de hand werken (Martens, 2016). Het is tevens de vraag wat de opkomst van buy-to-let per saldo gaat betekenen voor het woongenot van huurders. Hoe onderhouden verhuurders hun woningen en zijn ze voldoende aanspreekbaar op gebreken? De variatie onder verhuurders zal groot zijn, maar duidelijk is dat er momenteel een stijging plaatsvindt in het aantal amateurs dat woondiensten aanbiedt.

En hoewel onder veel omstandigheden meer huuraanbod leidt tot een betere betaalbaarheid (lagere huren), kan dit ten tijde van een woningtekort juist omge- 
keerd werken. Er kan dan een perverse feedbackloop ontstaan waarbij de extra koopvraag door buy-to-let de prijzen voor koopwoningen verder doet stijgen, waardoor kopen buiten bereik van bepaalde groepen komt, waardoor de vraag naar huren toeneemt, vervolgens de huurprijzen stijgen, hetgeen dan weer meer buy-to-let-aankopen uitlokt, enzovoort. In dat geval zou buy-to-let tijdens perioden van woningschaarste de betaalbaarheid op zowel de koopmarkt als de huurmarkt onder druk kunnen zetten.

Daarnaast kijkt de nieuwe groep buy-to-let-kopers, net als grote beleggers, door een andere bril naar haar beleggingswoningen dan eigenaars-bewoners doen: de woning als verdienmodel in plaats van de woning als het persoonlijk thuis. Het valt te bezien wat dit betekent wanneer de marktomstandigheden wijzigen. Bijvoorbeeld als de rente stijgt of als de huizenprijzen dalen. Blijken ze dan juist een stabiliserende factor? Of valt ten tijde van gewijzigde marktomstandigheden de buy-to-let-vraag dan ver terug en, sterker, komen deze woningen dan massaal op de markt met extra prijsdalingen tot gevolg?

Wanneer buy-to-let-aankopen (deels) gefinancierd worden met hypotheken, bestaat het risico dat deze massaal verliesgevend worden bij gewijzigde marktomstandigheden. Bijvoorbeeld wanneer de rente stijgt of de markthuren dalen. Uit de Verenigde Staten is bekend dat in de periode 2005-2008, ten tijde van rentestijgingen, er een grote stijging van buy-to-let-faillissementen is opgetreden, en recent onderzoek suggereert dat dit de hoofdaanleiding is geweest voor de financiële crisis van 2008 (Albanesi, De Giorgi \& Nosal, 2017).

In de Nederlandse situatie is momenteel een toename van het aantal aanbieders van buy-to-let-hypotheken te zien. De norm voor zulke hypotheken is doorgaans maximaal 80 procent loan-to-value en maximaal 60 procent aflossingsvrij. Dit klinkt conservatief in vergelijking met de hypotheek voor de eigen woning. Het risico is echter niet zozeer dat de woning onder water komt de staan, als wel dat de buy-to-let-constructie verliesgevend wordt. Dat kan de aanleiding vormen voor een verkoop- en liquidatiegolf. De marges zijn dun in de huidige markt. In het hiervoor gegeven praktijkvoorbeeld van de Amsterdamse Pijp zou bij een huur van $€ 1600$ per maand en 80 procent financiering tegen een rente van 5,0 procent de buy-to-let-constructie verliesgevend worden. In het Verenigd Koninkrijk heeft men recentelijk maatregelen getroffen en in 2017 een stress-test verplicht gesteld voor het verkrijgen van een buy-to-let-hypotheek. ${ }^{18}$

\section{Een blik op de transactieaantallen}

Figuren 1 en 2 tonen de transactieaantallen per type koper (starter - doorstromer - particuliere belegger) over een periode van elf jaar van begin 2007 tot en met eind 2017. De transactieaantallen in de grafieken tonen per type koper het aantal transacties in de voorgaande twaalf maanden. De data komen van DNB en die baseert de buy-to-let-aantallen op brongegevens van het kadaster. ${ }^{19}$ Figuren 1 en 2 tonen dat buy-to-let een serieuze factor is geworden op de Nederlandse koopwoningmarkt: 


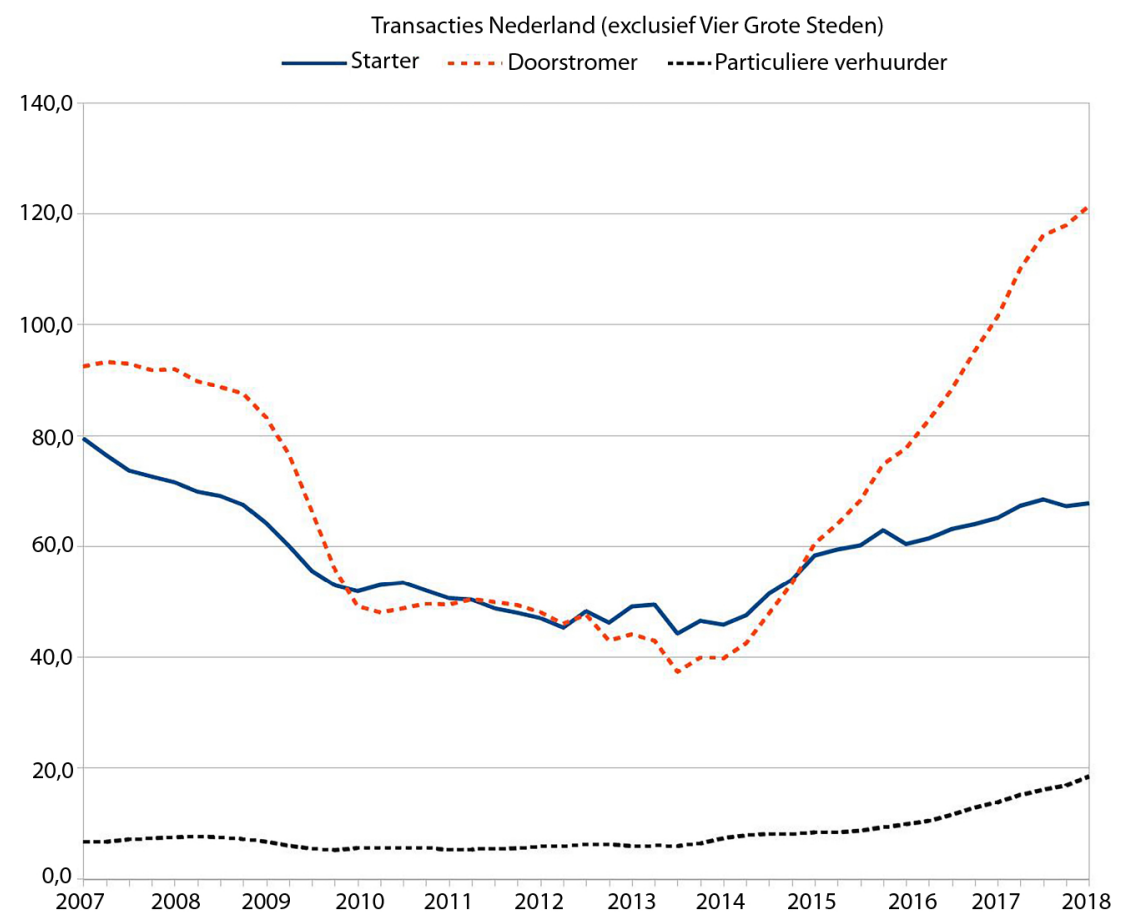

Figuur 1 Transactieaantallen Nederland (excl. vier grote steden) over 2007-2017. In duizenden, 1 jaar voortschrijdend (bron: DNB, Overzicht Financiële Stabiliteit Voorjaar 2018)

- De buy-to-let-aantallen in zowel de vier grote steden als in het totaal van de rest van Nederland beginnen aan een voorzichtige opmars in 2014, en deze komt op stoom in de loop van 2015 rond het moment dat de spaarrente zakte door het fiscale break-evenpoint van 1,2 procent.

- De trend van een groeiend aantal buy-to-let-transacties heeft zich ook in de meest recente periode gestaag doorgezet; het einde lijkt niet in zicht.

- Buy-to-let is groter in de steden dan in de rest van het land, maar de relatieve stijging van buy-to-let was nagenoeg gelijk (een verdrievoudiging), gemeten over de jaren 2010-2017 (+ 235 procent in Nederland, +230 procent in de vier grote steden).

- Buy-to-let is inmiddels een aanzienlijke speler binnen de transacties in de grote steden (marktaandeel meer dan 20 procent in 2017), en meer bescheiden in de rest van Nederland (bijna 10 procent). De buy-to-let-aantallen vertegenwoordigen wel nog altijd een klein deel van de woningvoorraad: de groei van de particuliere huursector verloopt traag (zie eerder bij achtergronden). 


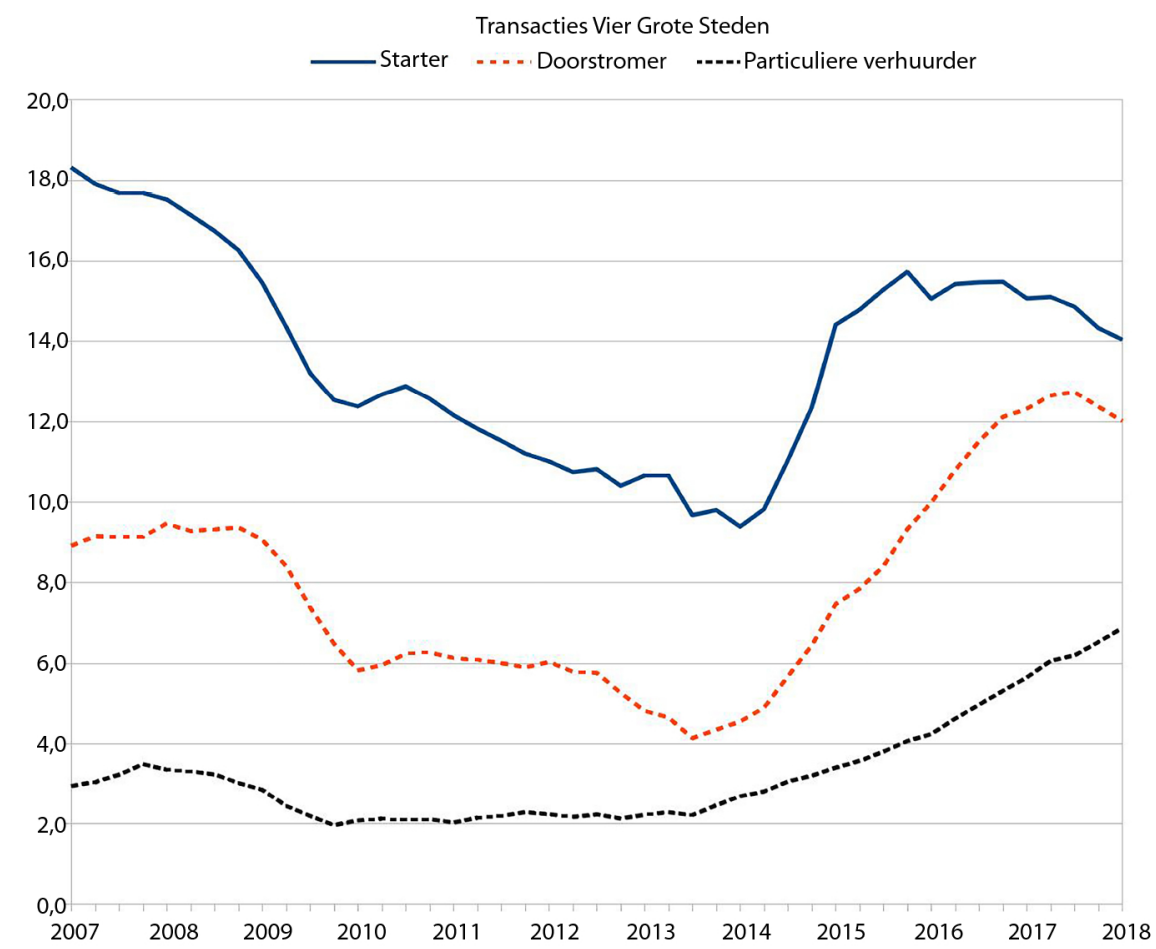

Figuur 2 Transactieaantallen vier grote steden over 2007-2017. In duizenden, 1 jaar voortschrijdend (bron: DNB, Overzicht Financiële Stabiliteit Voorjaar 2018)

Er valt meer interessants te zien in figuren 1 en 2. Zo is duidelijk te zien dat in de grote steden al jaren een 'startersmarkt' heerst waarbij de meeste kooptransacties plaatsvinden door koopstarters. Buiten de grote steden zijn het vaker doorstromers die de markt maken (deels afkomstig uit de grote steden). En ondanks vele geluiden dat starters het moeilijk hebben op de huidige markt, valt te zien dat de starter een imposante opmars heeft gemaakt sinds 2014 (meer dan 45 procent stijging in zowel de grote steden als daarbuiten). ${ }^{20}$ Mocht er sprake zijn van verdringing van starters op de markt voor koopwoningen, dan kan desalniettemin gesteld worden dat er anno 2017-2018 meer starters toetreden dan tijdens de periode dat het een zogeheten startersmarkt was (2009-2014).

Kwam het koopwoningmarktherstel in 2014 door de opkomst van buy-to-let?

In 2014 was er een plotselinge opleving op de koopwoningmarkt. Transactieaantallen schoten omhoog (zie ook figuren 1 en 2), maar het prijsniveau bleef nagenoeg gelijk. Er werden in 2014 in heel Nederland ruim 43.000 meer woningen verkocht dan in 2013 (+ 39 procent) en ook veel meer dan in de jaren daarvoor. De toename in buy-to-let-aankopen echter was in 2014 beperkt: zo'n 2000 woningen (van 10.000 naar 12.000 transacties; data: DNB). Deze toename was trendmatig 
en zeer klein ten opzichte van de toename van 43.000 transacties in de hele markt. De opkomst van buy-to-let kan niet als verklaring dienen voor de opleving van de koopwoningmarkt in 2014. Wat we zien is dat in 2014 de transactieaantallen bij zowel starters $(+18.000)$ als doorstromers $(+24.000)$ plotseling omhoogschieten (data: DNB). Dit vond plaats zonder wezenlijke prijsstijgingen en heeft daardoor onder de radar kunnen plaatsvinden.

Voor de verklaring moeten we kijken naar de tijdelijke verruiming van de eenmalige schenkingsvrijstelling tot $€ 100.000$ die gold van 1 oktober 2013 tot en met 31 december 2014. Wie geld schonk ten behoeve van de koop of aflossing van het eigen huis, kon dit belastingvrij doen tot een bedrag van $€$ 100.000. De regeling was onverwacht populair en er werd massaal gebruik van gemaakt. De Rekenkamer concludeert dat op deze manier ongeveer 159.000 keer is geschonken, waarbij de gemiddelde schenking circa $€ 60.000$ betrof (Algemene Rekenkamer, 2017). Hierdoor is eind 2013 en in 2014 (en nog twee jaren daarna ${ }^{21}$ ) in totaal in de orde van grootte van $€ 10$ miljard spaargeld van schenkers de woningmarkt ingestroomd. In ongeveer 33.000 gevallen is dit gebruikt voor een startersaankoop, en zo'n 118.000 keer heeft dit geleid tot vervroegd aflossen. ${ }^{22}$

Dit verklaart waarom starters in 2014 in beweging kwamen en het verklaart hoe een hele groep eigenaren zich kon verlossen van hun onderwaterhypotheken en daardoor weer durfde door te stromen.

De tijdelijke verruimde schenkingsvrijstelling vormde de kickstart van de woningmarkt in $2014 .^{23}$

\section{4-2018: economisch herstel en dalende rentes}

De omstandigheid wil dat juist in de loop van 2014 en de jaren daarna er nog twee ontwikkelingen waren die de wind flink onder de zeilen heeft gezet op de woningmarkt. Ten eerste het macro-economische tij. Nederland was in 2013 uit een recessie gekomen, de economie groeide weer en na een aantal jaren van stijgende werkloosheid begon deze nu duidelijk te dalen in de loop van 2014 (een trend die anno 2018 nog steeds gaande is). Ten tweede, en mogelijk van nog grotere invloed, vond er een zeer sterke daling van de hypotheekrente plaats. De 10-jarige hypotheekrente daalde over 2014-2018 van bijna 5 procent naar 2 procent. Hierdoor kan de kickstart van de koopwoningmarkt een krachtig vervolg krijgen. Meer starters en doorstromers komen weer in beweging, prijzen stijgen, het aantal onderwaterhypotheken neemt af, nog meer doorstromers worden actief... Een nieuwe boom is geboren. Tegelijkertijd zet de spaarrente een stevige daling in en wordt, zoals hierboven beschreven, tevens een buy-to-let-boom geboren.

\section{Doorstromers vormen bron van instabiliteit}

Eén punt verdient zeker nog opgemerkt te worden. Wat vooral opvalt bij een eerste blik op figuur 1 (transactieaantallen Nederland, exclusief vier grote steden) is de enorme fluctuaties in aantallen transacties over de jaren heen en dan vooral bij doorstromers. Doorstromers haakten abrupt en massaal af na het begin van de financiële crisis in 2008 (tot ongeveer 50.000 minder doorstroomtransacties op jaarbasis in 2013 versus vlak voor de financiële crisis; Nederland, exclusief vier grote steden). Bijna 70 procent van de marktuitval kwam door het wegvallen van 
doorstromers. Sinds 2014 is er weer een doorstroomhausse ontstaan (plus 80.000 transacties op jaarbasis anno 2018 versus 2014; data: DNB). De doorstromers vormen een grote bron van instabiliteit, met risico op zowel periodes van hausse als periodes van vraaguitval.

Daarbij genereren doorstromers verreweg de meeste marktomzet (want zijn met velen en kopen gemiddeld duurdere woningen) en zijn dus van grote invloed op de prijsvorming. Een nieuwe prijsboom kan dan ook niet los worden gezien van de rol van doorstromers op onze woningmarkt. Dalende rentes lokken daarbij ook een doorstroombeweging uit: bij een verhuizing kan zonder boetes worden overgesloten van een hoge hypotheekrente naar een lagere. Verhuizen is op die manier goedkoper dan verbouwen en zo hoeft wonen in een duurder huis niet meer te kosten. Er lijkt vanuit macro-economisch perspectief geen goede reden voor het nut van een financiële prikkel die verhuizen bevoordeelt boven verbouwen.

Daarbij zij opgemerkt dat doorstromers hun oude aflossingsvrije hypotheken tegen de nieuwe lagere rente mogen meenemen naar hun nieuwe woning. ${ }^{24} \mathrm{Het}$ is daarom zeer wel denkbaar dat de huidige prijsniveaus voor een belangrijk deel bepaald worden door nieuwe goedkope aflossingsvrije hypotheken. Starters moeten sinds 2013 wél volledig aflossen (voor de aflosverplichting zijn goede redenen). Deze tweedeling zet starters op een achterstand (nú, én als ze later nog mochten willen doorstromen) en geeft het risico van prijsopdrijving door doorstromers. Dit is het gevolg van de keuze om bij de invoering van de aflossingsverplichting in 2013 bestaande aflossingsvrije gevallen te ontzien gedurende dertig jaar. Voor de stabiliteit van de woningmarkt zou het mogelijk beter zijn als ook doorstromers verplicht zouden worden tot aflossen, bijvoorbeeld door te verlangen dat het voordeel van lagere rentelasten wordt aangewend om af te lossen.

\section{Tijd voor beleid?}

De realiteit is dat er weinig bekend is over de effecten van buy-to-let op de Nederlandse woningmarkt. Daardoor is het een uitdaging om grondig gefundeerd te kunnen stellen of deze ontwikkeling per saldo juist bijdraagt of afbreuk doet aan de gezondheid van de woningmarkt in zijn geheel (koop én huur). In het geval van toeristische verhuur van reguliere woningen (Airbnb) en buy-to-leave is dat duidelijker. Het is in die gevallen evident dat er direct woningen worden onttrokken aan de beschikbare voorraad, de woonkrapte neemt toe. Ten tijde van een woningtekort staan toeristische verhuur en buy-to-leave dan ook op gespannen voet met het grondrecht van wonen. In het geval van buy-to-let ligt dat subtieler. Bij buy-to-let is sprake van een omzetting binnen de woningvoorraad (koop wordt huur) en dient de vraag te zijn of de voorraad hiermee per saldo beter aansluit op de huidige en toekomstige woonvraag in de markt, en of deze ontwikkeling bijdraagt aan de betaalbaarheid en toegankelijkheid van wonen. Ten opzichte van enkele andere landen (zoals het Verenigd Koninkrijk) staat de buy-to-let-ontwikkeling hier in de kinderschoenen. Het zou daarom zinvol zijn om verder te onderzoeken welke knelpunten er zijn ontstaan in meer volwassen buy-to-let-markten. 
Dat er nieuwe risico's zijn is wel duidelijk. Nieuwe risico's vragen doorgaans om aanvullend beleid. Het verdient aanbeveling om eventuele beleidswijzigingen omtrent buy-to-let te toetsen aan de effectiviteit, op korte en op lange termijn, ten aanzien van:

- verbetering van betaalbaarheid en toegankelijkheid van koop én huur (en koop en huur daarbij zo nodig tegen elkaar af te wegen);

- vermindering van stabiliteitsrisico's voor de Nederlandse woningmarkt.

We kunnen ter illustratie op deze manier enkele mogelijke voorstellen kort doorlichten:

- Maatregelen die buy-to-let-hypotheken beperken of uitbannen verminderen aanzienlijk de risico's op (en de effecten van) een toekomstige buy-to-let-verkoopgolf en dragen daarmee bij aan de stabiliteit van de woningmarkt (voorbeelden zijn de stress-test zoals ingevoerd door de Bank of England en een aflosverplichting voor buy-to-let-hypotheken).

- Maatregelen tegen onttrekking aan de woningvoorraad dragen bij aan meer reguliere woningen die beschikbaar zijn voor verhuur of koop en verbeteren daarmee de betaalbaarheid en toegankelijkheid van zowel de huur- als de koopmarkt. Voorbeelden van zulke maatregelen zijn: het voorkomen van hypotheekverstrekking op basis van inkomsten uit toeristische verhuur (Airbnb), ${ }^{25}$ alsmede het uitbannen van toeristische verhuur ten tijde van aanzienlijke woningtekorten en het voorkomen van buy-to-leave (leegstand).

- Een fiscale maatregel zoals een verhoogde overdrachtsbelasting lijkt weinig effectief. Het effect op de buy-to-let-beleggingsbeslissing is beperkt en deze maatregel draagt niet bij aan betaalbare huren (zoals beschreven in de paragraaf over het buy-to-let-verdienmodel, voetnoot 4). Dit geldt in de praktijk tevens voor veel andere mogelijke fiscale maatregelen.

- Maatregelen die de huurprijzen in de vrije sector begrenzen (zoals een maximaal aanvaardbare prijs per vierkante meter), leiden direct tot verbeterde betaalbaarheid van huren en doen de buy-to-let-vraag afkoelen (de beleggingswaarde van woningen daalt), hetgeen ook de betaalbaarheid op de koopmarkt ten goede kan komen (zoals beschreven in de paragraaf over het buy-to-letverdienmodel, voetnoot 4). Hetzelfde geldt voor het begrenzen van het aantal WOZ-punten dat kan worden gescoord voor de puntenhuurprijs ((woningwaarderingsstelsel, WWS).

- Het werken met een betaalbaarheidstoets (zoals de Nibud-huurtool) als onderdeel van een huisvestingsvergunning in de vrije sector draagt op individueel niveau bij aan betaalbare huren, vermindert de kapitaalkrachtige vraag naar huur (en dus naar buy-to-let), maar heeft op korte termijn waarschijnlijk een negatief effect op de toegankelijkheid.

- Een toename van betaalbare alternatieven zal buy-to-let-huurprijzen doen afnemen (en als gevolg daarvan is er minder buy-to-let-vraag op de koopwoningenmarkt) en komt daarmee ten goede aan de betaalbaarheid en toegankelijkheid. Voorbeelden zijn corporatiebouw voor de middeninkomens en een verhoging van de inkomensgrens voor de sociale-huursector. 


\section{Conclusie}

De Nederlandse woningmarkt staat onder spanning. De koopwoningmarkt verkeert in een hausse en op de huurmarkt zijn de prijzen hard gestegen. In de jaren na aanvang van de financiële crisis van 2008 is de groei van de woningvoorraad ver achtergebleven bij de groei van het aantal huishoudens, waardoor er een aanzienlijk woningtekort is ontstaan. De toegankelijkheid en betaalbaarheid van wonen staan onder druk. Tegelijkertijd is in de afgelopen paar jaar buy-to-let (koop-voor-verhuur) een nieuwe factor van betekenis geworden op de Nederlandse koopwoningmarkt.

Dit artikel schetst de recente opkomst, de mechanismen en de risico's achter buyto-let op de Nederlandse woningmarkt. Buy-to-let heeft in recente jaren een opvallend grote groei doorgemaakt, een verdrievoudiging ten opzichte van de jaren voor 2014. De groei lijkt zich door te zetten.

Buy-to-let voorziet in een vraag naar huurwoningen (starters, expats, studenten), maar vist tegelijkertijd in de markt voor koopwoningen, terwijl het daar al druk is. Vooral vanwege de drukte op de koopwoningmarkt klinken er oproepen om buyto-let af te remmen (Aalbers e.a., 2018; Lennartz e.a., 2018).

Er is weinig bekend over het netto-effect van buy-to-let op de gehele Nederlandse woningmarkt (koop én huur). Toeristische verhuur (Airbnb) en buy-to-leave onttrekken woningen aan de woningvoorraad. Dat staat ten tijde van woningschaarste op gespannen voet met het grondrecht op wonen. Buy-to-let daarentegen resulteert in omzettingen binnen de woningvoorraad van koop naar huur en kan daarmee tegelijkertijd zowel negatieve als positieve effecten hebben.

De opkomst van buy-to-let brengt nieuwe risico's met zich voor de woningmarkt. Dat vraagt om maatregelen die deze risico's in goede banen leiden. Het zou daarbij verstandig zijn om beleidswijzigingen te toetsen aan hun effect op de betaalbaarheid en toegankelijkheid van wonen (koop én huur), en op hun effect op de stabiliteitsrisico's op de woningmarkt.

Tot slot bestaat het gevaar dat de rol van buy-to-let binnen de huidige hausse te groot wordt ingeschat. Het is problematisch wanneer daarbij andere risico's over het hoofd worden gezien of geen prioriteit krijgen. Alhoewel buy-to-let sterk gegroeid is, vertegenwoordigt het nog altijd een minderheidssegment.

Het leeuwendeel van het aantal transacties komt momenteel door doorstromers, daarna starters en ver daar achteraan pas buy-to-let. Zo ligt buy-to-let niet ten grondslag aan de start van het herstel van de koopwoningmarkt in 2014 (dat kwam door de tijdelijk verruimde schenkingsvrijstelling). De opkomst van buy-tolet ten tijde van de hausse sinds 2015 draagt zeker bij aan de drukte op de woningmarkt. Maar het is daarbij ook van belang om oog te hebben voor het risico dat doorstromers een sterkere bron van instabiliteit op de koopwoningmarkt lijken te vormen door hun hevig conjuncturele (wisselende) vraag en hun grote aantallen. De mogelijk ontwrichtende werking waarmee deze groep haar oude aflossingsvrije rechten nu opnieuw kan inzetten om tegen hoge prijzen door te stromen, zou maar zo een nieuwe bubbel kunnen voeden, en daarmee starters (zónder die rechten) voor lange tijd op onoverbrugbare afstand kunnen zetten. 


\section{Noten}

1 Enkele positieve effecten worden genoemd, maar niet verder uitgediept of geanalyseerd.

2 Kosten beslaan naast onderhoud, verzekeringen en lokale heffingen onder meer vervanging (renovatie), verhuurcourtage en leegstand. Enkele verdere aannames zijn: oplevering gestoffeerd, niet gemeubileerd, erfpacht buiten beschouwing gelaten, aankoop tegen vraagprijs, financiering volledig met eigen geld. Indien de helft hypothecair wordt gefinancierd tegen 3,5 procent rente (en de andere helft met eigen geld), resulteert een netto rendement van 4,3 procent (op eigen geld; op de totale investering is dat 2,2 procent). We beschouwen het huurrendement exclusief (ongerealiseerde) winsten of verliezen door woningprijsfluctuaties. Eigen berekeningen auteur.

3 Eigen berekening auteur. Berekeningen op basis van bruto rendementen leiden tot vergelijkbare conclusies.

4 Een overdrachtsbelasting van 15 procent zou in dit voorbeeld het bruto/netto huurrendement verlagen naar 4,7 procent/3,5 procent en zou de beleggingsbeslissing niet wezenlijk beïnvloeden. De huur-/beleggingswaarde van het object zou dan 13 procent (15 procent - 2 procent) afnemen. Zo'n overdrachtsbelasting heeft geen direct effect op de markthuur die een verhuurder kan vragen. Ervaringen met de Foreign Home Buyers Tax in Vancouver tonen een tijdelijke onderbreking van huizenprijsstijgingen.

5 Stel dat de maximale huurprijs voor dit appartement begrensd zou worden op $€ 1000$ per maand. Dan zou het bruto/netto rendement dalen naar 3,3 procent/2,2 procent. Indien deze belegger werkt met een huurrendementseis van netto 3,0 procent, dan zou bij $€ 1000$ per maand deze belegger kunnen gaan tot maximaal een transactieprijs van $€ 260.000$. Dit geeft een daling in huur-/beleggingswaarde van bijna 50 procent (van $€ 460.000$ naar $€ 260.000)$. Eigen berekening auteur.

6 Vóór die tijd lag de regie van de totale bouwproductie veel meer bij de centrale overheid en werd de bouwproductie meer bepaald op basis van demografische ontwikkelingen op de lange termijn in plaats van de marktvraag op korte termijn.

7 Schattingen van de gemeente Amsterdam spreken van een stijging van 39.000 expats in de hoofdstad in 2009 tot 77.000 expats in 2015 (plus 38.000). De woningvoorraad groeide in dezelfde periode met slechts ongeveer 14.000 woningen van 403.000 woningen naar 417.000 woningen (bron: Amsterdam OIS; eigen correctie vanwege wijziging in de telling).

8 Inmiddels werkt de regering aan een verruiming van de mogelijkheden om te bouwen voor de middeninkomens.

9 Bij een aflossingsvrije hypotheek wordt aflossen uitgesteld tot het einde van de looptijd. Gedurende de looptijd zijn alleen rentebetalingen verschuldigd.

10 De woningvoorraad groeide over dezelfde periode met ongeveer 20.000 woningen van 408.000 naar 428.000 (bron: Amsterdam OIS; eigen correctie vanwege wijziging in de telling).

11 Over de jaren 2011-2017 zijn in totaal in Amsterdam 69.299 woningen verkocht (Kadaster). Als we ruim rekenen met een bovengrens van 25 procent buy-to-let-transacties, dan komt dit neer op zo'n 17.500 woningen. Een realistischer schatting geeft circa 13.000 buy-to-let-transacties in Amsterdam over de jaren 2011-2017. 
12 Indien een huurder nog gereguleerd woont, dan vervalt de huurprijsbescherming pas voor de volgende huurder.

13 Indien een doorstroommarkt gepaard gaat met stijgende koopprijzen, gedijt deze markt bij dalende rentes: huizen langs de gehele ladder worden duurder; doorstromers financieren dit door overwaarde mee te nemen en door tegen lagere rentes te (her)financieren; starters stromen in tegen hogere prijzen die gefinancierd kunnen worden door lagere rentes (of versoepelde hypotheeknormen). Sinds begin jaren tachtig tot aan recent is er een klimaat geweest van dalende rentes.

14 Dit zijn onnodige onttrekkingen in de zin dat ze geen verband houden met sloop of een dringende herbestemming. Het is de vraag of deze onttrekkingen ten tijde van een woningtekort niet strijdig zijn met het grondrecht op wonen.

15 Op basis van een stel zonder kinderen in een eengezinswoning met energielabel C. Zie de Bo-Ex Huurwijzer of de !WOON Woonlastencheck, ontwikkeld door Nibud.

16 Veel kamers worden alsnog boven de maximale huurprijs aangeboden, maar kamerhuurders kunnen in dat geval naar de huurcommissie stappen.

17 Segregatie is de clustering van groepen en kan bredere maatschappelijke problemen in de hand werken. Segregatie raakt tevens aan de maatschappelijke vraag 'Van Wie is de Stad'?.

18 In het Verenigd Koninkrijk is sinds het jaar 2000 een opkomst geweest van buy-tolet-hypotheken, hetgeen heeft bijgedragen aan de groei van de buy-to-let-markt daar. In 2017 was in het Verenigd Koninkrijk het marktaandeel van buy-to-let onder nieuwe hypotheken 14 procent (Council of Mortgage Lenders).

19 Het is niet duidelijk hoe hierbij rekening wordt gehouden met 'verborgen' buy-to-lettransacties, waarbij een eigenaar-bewoner na verhuizing zijn oude koopwoning aanhoudt voor de verhuur. Tevens lijkt er geen saldering plaats te vinden met buy-to-letverkopen aan eigenaars-bewoners. De analyse vindt plaats onder de veronderstelling dat deze effecten beperkt zijn.

20 In de media wordt regelmatig melding gemaakt van het lage aandeel starters ( procent) in de transactieaantallen. Terwijl in absolute termen het aantal starters hoog is, is het aandeel starters gedaald en erg laag vanwege de extreem hoge aantallen doorstromers.

21 Ontvangers van schenkingen kregen drie jaar de tijd om de schenking aan te wenden.

22 Aantallen op basis van percentages uit het rapport van de Algemene Rekenkamer.

23 Per 1 januari 2017 is de vrijstelling heringevoerd als een permanente vrijstelling tot $€ 100.000$ ter aanwending van de eigen woning voor ontvangers onder de 40 jaar oud.

24 De aanvullende benodigde financiering dient wel volledig te worden afgelost om aanspraak te maken op hypotheekrenteaftrek.

25 Bij de eigenwoninghypotheek zijn de inkomsten uit arbeid en andere bestendige inkomsten leidend. Airbnb valt daar niet onder. Desondanks becijferde het ING Economisch Bureau in 2016 dat de Amsterdamse Airbnb voor verhuurders gemiddeld voldoende oplevert om ongeveer een ton hogere hypotheek mee te financieren. Dit kan kopers aanzetten tot financieel riskant gedrag, waarmee via een omweg Airbnbinkomsten tóch in de hypotheekverstrekking kunnen belanden. 


\section{Literatuur}

Aalbers, M., Bosma, J., Fernandez, R., \& Hochstenbach, C. (2018). Buy-to-let gewikt en gewogen. (onderzoeksrapport in opdracht van De Socialistische Partij). Leuven/ Amsterdam: KU Leuven/Universiteit van Amsterdam.

Albanesi, S., De Giorgi, G., \& Nosal, J. (2017). Mortgage default during the Great Recession came from real estate investors, not subprime credit holders. CEPR Policy Portal.Voxeu.org.

Algemene Rekenkamer (2017). Schenkingsvrijstelling eigen woning. Effecten op de hypotheekschuld.

DNB (2018). Overzicht Financiële Stabiliteit Voorjaar 2018.

Faessen, W., Gopal, K., Leeuwen, G. van, \& Omtzigt, D. (2017). Primos 2017. Prognose van bevolking, huishoudens en woningbehoefte 2017-2050. ABF Research.

Lennartz, C., Baarsma, B., \& Vrieselaar, N. (2018). Exploderende huizenprijzen: vijf beleidsopties. Economisch Commentaar. RaboResearch, 1-4.

Martens, M. (2009). De implosie van een woningmarkt. Tijdschrift voor Volkshuisvesting, juni: 12-17.

Martens, M. (2016). Nieuwe woningmarktbubbel met nieuwe risico's door opkomst buyto-let. Me Judice : 1-8.

Ministerie van Binnenlandse Zaken en Koninkrijksrelaties (2016). Wonen in Beweging. De resultaten van het WoonOnderzoek Nederland 2015.

Planbureau voor de Leefomgeving (2017). Middeninkomens op de Woningmarkt. Ruimte op een krap speelveld. PBL Policy Brief.

Tweede Kamer der Staten Generaal (2013). Kosten Koper. Eindrapport; een reconstructie van 20 jaar stijgende huizenprijzen.

Vries, P. de, Brugmans, L., \& Harleman, F. (2017). Verdringt de particuliere verhuurder de starter van de koopwoningmarkt? Kadaster: 1-3. 